STUDIES IN POPULAR CULTURE
Time, work

\section{and leisure}

Life changes in England since 1700 HUGH CUNNINGHAM

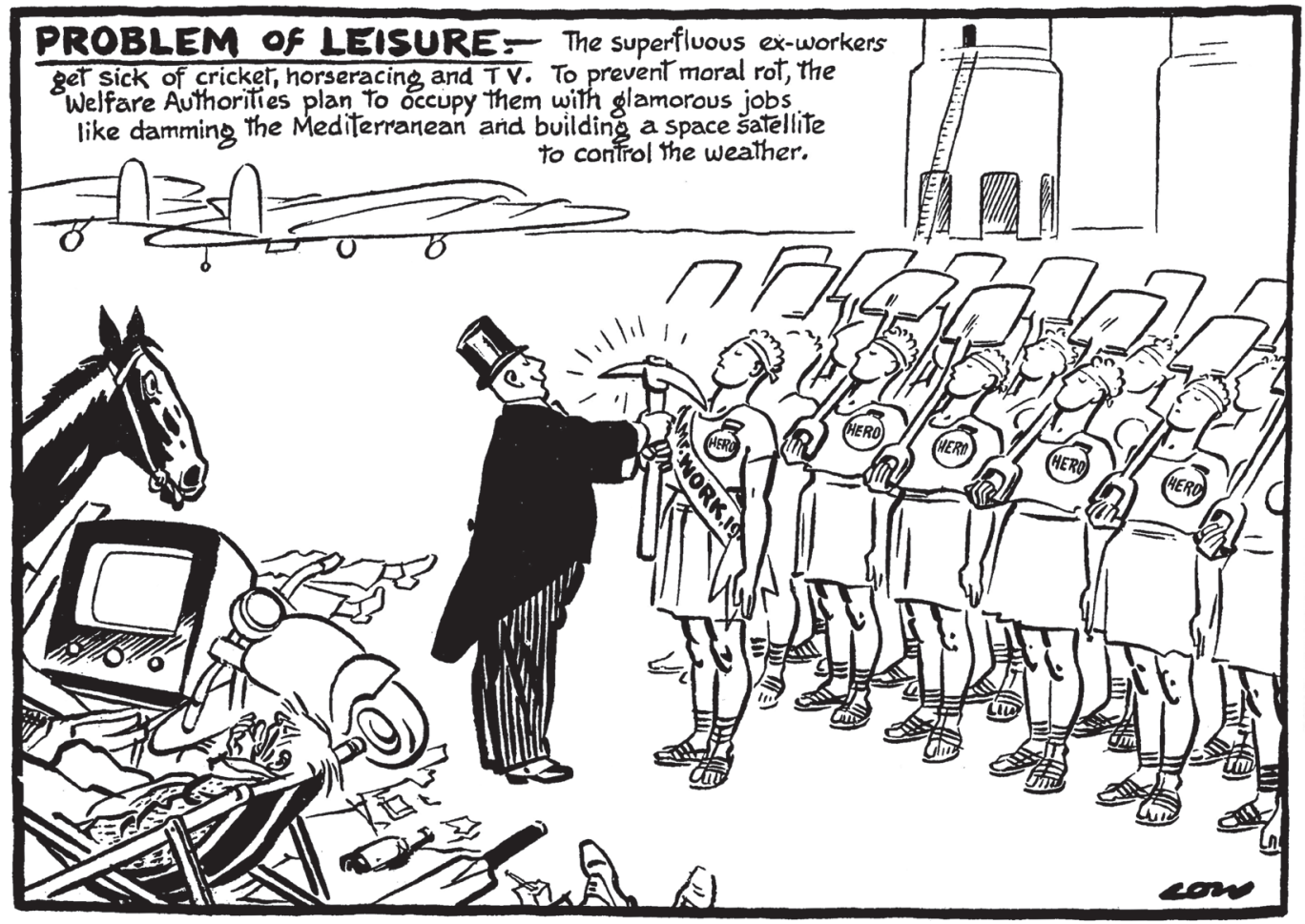




\section{Time, work and leisure}

\section{MANCHESTER \\ 1824}

Manchester University Press 


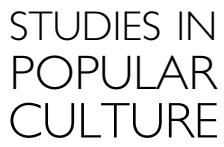

General editor: Professor Jeffrey Richards

Already published

Christmas in nineteenth-century England

Neil Armstrong

Healthy living in the Alps: the origins of winter tourism in

Switzerland, 1860-1914

Susan Barton

Working-class organisations and popular tourism, 1840-1970

Susan Barton

Leisure, citizenship and working-class men in Britain, 1850-1945

Brad Beaven

Leisure and cultural conflict in twentieth-century Britain

Brett Bebber (ed.)

The British Consumer Co-operative Movement and film, 1890s-1960s

Alan George Burton

British railway enthusiasm

lan Carter

Railways and culture in Britain

lan Carter

Darts in England, 1900-39: a social history

Patrick Chaplin

Relocating Britishness

Stephen Caunce, Ewa Mazierska, Susan Sydney-Smith and John Walton (eds)

Holiday camps in twentieth-century Britain: packaging pleasure

Sandra Trudgen Dawson

History on British television: constructing nation, nationality and collective memory

Robert Dillon

The food companions: cinema and consumption in wartime

Britain, 1939-45

Richard Farmer 
Songs of protest, songs of love: popular ballads in eighteenth-century Britain

Robin Ganev

Women drinking out in Britain since the early twentieth century

David W. Gutzke

The BBC and national identity in Britain, 1922-53

Thomas Hajkowski

From silent screen to multi-screen: a history of cinema exhibition in Britain since 1896

Stuart Hanson

Smoking in British popular culture, 1800-2000

Matthew Hilton

Juke box Britain: Americanisation and youth culture, 1945-60

Adrian Horn

Popular culture in London, c. 1890-1918: the transformation of entertainment

Andrew Horrall

Horseracing and the British, 1919-39

Mike Huggins

Popular culture and working-class taste in Britain, 1930-39:

a round of cheap diversions?

Robert James

Amateur operatics: a social and cultural history

John Lowerson

Scotland and the music hall, I850-19|4

Paul Maloney

Amateur film: Meaning and practice, 1927-1977

Heather Noris Nicholson

Films and British national identity: from Dickens to Dad's Army Jeffrey Richards

Cinema and radio in Britain and America, 1920-60

Jeffrey Richards

Looking North: Northern England and the national imagination

Dave Russell

The British seaside holiday: holidays and resorts in the twentieth century

John K. Walton 
Hugh Cunningham - 9781526112293 Downloaded from manchesterhive.com at 04/26/2023 01:11:54PM via free access 


\title{
Time, work and leisure
}

Life changes in England since 1700

\section{HUGH CUNNINGHAM}

\author{
Manchester University Press \\ Manchester and New York
}

distributed in the United States exclusively by Palgrave Macmillan 
Copyright (c) Hugh Cunningham 2014

The right of Hugh Cunningham to be identified as the author of this work has been asserted by him in accordance with the Copyright, Designs and Patents Act 1988.

Published by Manchester University Press

Oxford Road, Manchester MI3 9NR, UK

and Room 400, 175 Fifth Avenue, New York, NY 10010, USA

www.manchesteruniversitypress.co.uk

Distributed in the United States exclusively by

Palgrave Macmillan, 175 Fifth Avenue, New York,

NY 10010, USA

Distributed in Canada exclusively by

UBC Press, University of British Columbia, 2029 West Mall,

Vancouver, BC, Canada V6T IZ2

British Library Cataloguing-in-Publication Data

A catalogue record for this book is available from the British Library

Library of Congress Cataloging-in-Publication Data applied for

ISBN 9780719085208 hardback

First published 2014

The publisher has no responsibility for the persistence or accuracy of URLs for any external or third-party internet websites referred to in this book, and does not guarantee that any content on such websites is, or will remain, accurate or appropriate.

Typeset in 10/14pt Adobe Garamond

by Graphicraft Limited, Hong Kong 


\section{STUDIES IN \\ POPULAR \\ CULTURE}

There has in recent years been an explosion of interest in culture and cultural studies. The impetus has come from two directions and out of two different traditions. On the one hand, cultural history has grown out of social history to become a distinct and identifiable school of historical investigation. On the other hand, cultural studies has grown out of English literature and has concerned itself to a large extent with contemporary issues. Nevertheless, there is a shared project, its aim, to elucidate the meanings and values implicit and explicit in the art, literature, learning, institutions and everyday behaviour within a given society. Both the cultural historian and the cultural studies scholar seek to explore the ways in which a culture is imagined, represented and received, how it interacts with social processes, how it contributes to individual and collective identities and world views, to stability and change, to social, political and economic activities and programmes. This series aims to provide an arena for the cross-fertilisation of the discipline, so that the work of the cultural historian can take advantage of the most useful and illuminating of the theoretical developments and the cultural studies scholars can extend the purely historical underpinnings of their investigations. The ultimate objective of the series is to provide a range of books which will explain in a readable and accessible way where we are now socially and culturally and how we got to where we are. This should enable people to be better informed, promote an interdisciplinary approach to cultural issues and encourage deeper thought about the issues, attitudes and institutions of popular culture.

Jeffrey Richards 
Hugh Cunningham - 9781526112293 Downloaded from manchesterhive.com at 04/26/2023 01:11:54PM via free access 